\title{
PIGMENT ESTIMATION AND ANTI-MICROBIAL PROPERTY OF LEAF EXTRACTS OF DATURA STRAMONIUM L
}

\author{
L Rani ${ }^{1 *}$, D K Behera ${ }^{2}$, J Kumar ${ }^{3}$.
}

\begin{abstract}
1.Dr. Ladly Rani :Assistant Professor, University Department of Botany and Co-ordinator Biotechnology. Ranchi University (corresponding author)Email: ladlyrani@gmail.comPhone :9470347346

2.Dinesh Behera :M.Sc University Department of Botany, Ranchi University,Ranchi Dinesh.jsp08@gmail.com

3.Dr. Jyoti Kumar:H.O.D University Department of Botany ,Ranchi University, Ranchi jyotikumar1@gmail.com
\end{abstract}

\begin{abstract}
The present study was carried out on a poisonous plant but with high medicinal values \& traditional importance Datura stramonium, for the qualitative and quantitative estimation analysis of primary metabolites \& anti-microbial activity. Several methods have been developed for the estimation of these pigments.Plants are the richest source of natural antimicrobial agents. This study aims to conduct an estimation of pigment specifically the chlorophyll content in D. stramonium leaf, using Acetone, Methanol \& Ethanol as solvent for extraction, to compare the amount of pigments present in that species, as well as comparison of the antibacterial activity in each solution with Kirby-Baver standard interpretative method. Fresh leaves of $D$. stramonium collected from local area of Ranchi, Jharkhand; during January 2020. After the extraction of pigments using the three above mentioned solvents, analysed under UV- VIS spectrophotometry at wavelength $645 \mathrm{~nm} \& 663 \mathrm{~nm}$. Estimation of chlorophyll content was made using the methods of Arnon (1946). Comparison were made in between young \& mature leaf of Datura stramonium according to efficiency of work in different solvent. Paper Chromatograpy \& TLC (Thin layer chromatography) are also used as a part of qualitative estimation of primary and secondary metabolites. Like that for anti bacterial study culture natural agar nutrient prepared by taking $100 \mathrm{mg} / \mathrm{ml}$. in $50 \%$ DMSO, to grow human pathogenic bacteria, called Staphylococcus aureus \& E. coli.
\end{abstract}

KeyWords:-

Datura stramonium,

Estimation,

Antimicrobial activity,

UV-VIS

Spectrophotometry, Kirby- Bauer, DMSO. 


\section{Introduction}

Nature has a very rich botanical wealth and a large number of diverse types of plant grow in different parts of the country. There are various kind of medicinal plants present all over the world. The affordability, reliability, availability and low toxicity of medicinal plants in therapeutics made them popular and acceptable by all religions and implementation in health care all over the world (Akharaiyi, 2011). Plants have been producing a diverse range of bioactive molecules, making them rich sources of different types of medicines. Higher plants, sources of medicinal compounds have continued to play a dominant role in maintenance of human health since ancient times (Farombi, 2003). The study is carried out on Datura stramonium L., which has high medicinal values. This is commonly known as Jimson weed (CABI, November 2018) \& belongs to the family Solanaceae. Generally in typical Hindu families it's flower is used for worship purposes. Its leaves and branches extracts show high antimicrobial activities. The number of multidrug resistant microbial strains and the appearance of strains with reduced susceptibility to antibiotics are continuously increasing at the present time. Plant extracts have greater potential as antimicrobial compounds against microorganisms and that they can be used in the treatment of infectious disease caused by pathogens(Okoye et al., 2010).The leaf extract used to treat epilepsy and skin ulcer type of disease. These are Mostly found in temperate and subtropical region. (Ahad HA et al.2012). Commonly Datura occurs naturally on fertile wasteland, dry river banks and roadsides. They always start growing where the been listed as the cause of destruction of millions of lives throughout the globe, particularly the developing countries(8). To treat these diseases, the modern treatment mechanism have continuously been facing a problem due to associated side effects. Several pathogens have evolved immunity to multiple antibiotics as a result of the mutagenic characteristics of the bacterial genome, rapid multiplication and transformation of bacterial cells. The objective of the study was to analyse the qualitative and quantitative estimation of primary metabolites like Chl. A, Chl. B, Carotenoids as well as comparison of antimicrobial activity of the leaf extracts using the specified extraction solvents.

\section{Materials and Methods}

\section{A. Study area}

The present study was carried out at Ranchi University, Biotechnology lab., located at the Morabadi area of Ranchi district, Jharkhand,

\section{B. Collection of plant materials}

Datura stramonium L. is found almost all over the world. I had collected the fresh sample of the species from Shantinagar area of Namkum region, Ranchi district, Jharkhand, Pin- 834010. Namkum is located at $23^{\circ} 21^{\prime} \mathrm{N} 85^{\circ} 22^{\prime} \mathrm{E}$. The plant was authenticated by the department of Botany, Ranchi University.

\section{Extraction of Primary metabolites}

\section{For paper chromatography \& TLC screening}

The collected leaves were washed and cleaned with distilled water to remove dust and dried with absorbent paper. After drying $50 \mathrm{gms}$ of fresh leaves were takmenai mortar pestle which are chopped with sanitized scissor/ knefie. $F$ drops of ethanol/ acetone/ methanol was added in the mortar peedtle a then the leaves were crushed. Fresh leaves 
extract was collected in a watch glass. Chromatography chamber was filled by $100 \mathrm{ml}$ of $90 \%$ acetone solution $190 \mathrm{ml}$ Acetone+10ml distilled water). The choice of the solvent system depends on the properties of the components to be separated. Extract was loaded on the chromatography paper/ TLC for 5-6 times. Chromatography paper was adjusted in the chromatography chamber.hromatography paper was left inside the chromatography chamber for 1-2 hou

The components can be identified on the basis of the (Rf) values dedermmined f chromatogram,

$\mathrm{Rf}=$ (distance of the solute) /(distance of the solvent moves)

Where, $\mathrm{Rf}=$ Retention factor

2. For estimation of chlorophyll (Arnon1946)

One gram of finely crushed fresh leaves extract were taken and mixed with $25 \mathrm{ml}$ of $80 \%$ Acetone. It was then centrifuged at 5000 rpmfor 5 minutes. The supernatantwas transferred and the procedure repeated till the residue become colourless. The absorbance of the solution was read at $645 \mathrm{~nm}, 663 \mathrm{~nm}$ \& $500 \mathrm{~nm}$ against the solvent (acetone) blank.

The concentration of chlorophyll A, chlorophyll B, Carotenoids and total chlorophyll were calculated using the following equations_

Chlorophyll $A=12.7(663 \mathrm{~nm}) \quad-$ $2.69(645 \mathrm{~nm})$ Chlorophyll $B=$ $22.9(645 \mathrm{~nm})-4.68(663 \mathrm{~nm}) \quad$ Total chlorophyll= 20.2(645nm) + 8.02(663nm) Carotenoid = $0.354(500 \mathrm{~nm})$ $0.312(645 \mathrm{~nm})+0.39(663 \mathrm{~nm})$

D. Preparation of leaf extract for antimicrobial activity
$300 \mathrm{gms}$ of leaves rinsed with tap water and dried at room temperature. D. stramonium leaves were ground to a fine powder using an electronic grinder. The solvents used for extraction were ethanol, methanol, acetone and distilled water. Approximately, $50 \mathrm{~g}$ powder was blended with $150 \mathrm{ml}$. of each solvent. Orbital shaker was used for the extraction purpose in which the sample was subjected to continuous shaking for 3 successive days. The sample was then filtered out using Whatman No. 1 filter paper, then the filtrate was evaporated using a rotary evaporator under reduced pressure at $4^{\circ} \mathrm{C}$. The extract was pooledthe ca and dried and stored at $4^{\circ} \mathrm{C}$ in a refrigerator until screened for antibacterial activity. The stock solution was prepared by taking $100 \mathrm{mg} / \mathrm{ml}$ in $50 \%$ dimethyl sulfoxide (DMSO), mixed with vortex and stored at $4^{\circ} \mathrm{C}$ until use in the refrigerator.

\section{E. Bacterial culture}

A bacterial culture is a method of bacteria organisms by allowing them to reproduce in predetermined culture media under controlled laboratory conditions. For any bacterial culture, it is necessary to provide the suitable environmental and nutritional conditions that exist in its natural habitat. The bacterial strains, Escherichia coli, Staphylococcus aureus were used. The ampicillin-resistant Staphylococcus aureus \& streptomycin- resistant E. coli pure isolates used in this study were kindly provided by Department of Botany, Ranchi University. Microorganisms were grown into $10 \mathrm{ml}$. of nutrient agar at $37^{\circ} \mathrm{C}$ for $24 \mathrm{~h}$.

\section{F. Antibacterial activity assay}

The anti- microbial assay of ethanol, methanol \& acetone extraxt of young and old leaves of Datura stramonium were prepared by disc diffusion method. 
$7 \mathrm{gm}$. of nutrient agar was dissolved in 250 $\mathrm{ml}$. of distilled water and autoclaved. Under sterilized condition nutrient agar mediawas poured in to several petriplates and are allowed to cool down. After that 10ul. of standard inoculum of E. coli \& S.averus was spread on the surface of sterile nutrient agar plates.Sterile $6 \mathrm{~mm}$ disc with different plant extracts were placed and marked at the back side of each plates, with different microorganisms.Two different antibiotic discs were also placed as positive controls. The plates were incubated at $37^{\circ} \mathrm{C}$ for 24 hrs. The antimicrobial activity was detected by measuring zone of inhibition in milimeters. 


\section{Results and Discussions_}

Healthy and fresh leaves of Datura stramonium are collected from Namkum area of ranchi.
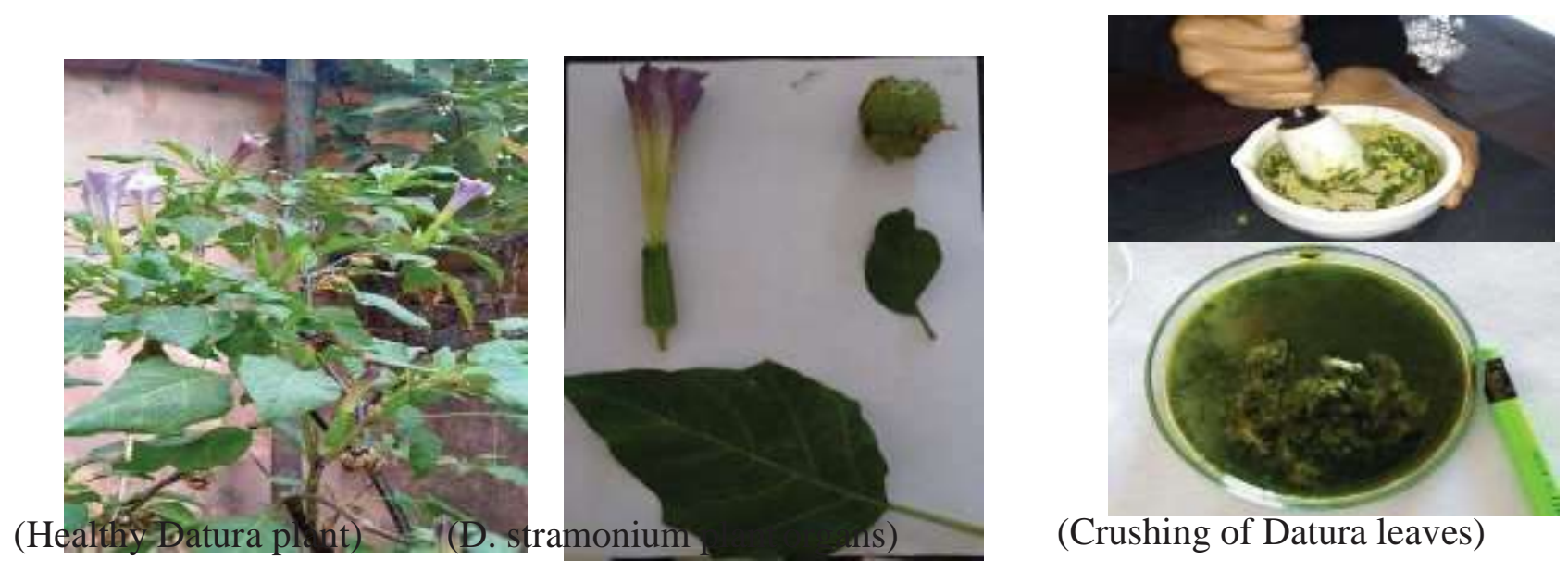

(Crushing of Datura leaves)

The screening of primary metabolites belongs to $D$. Stramonium in different solvent

\begin{tabular}{|c|c|c|c|}
\hline Solvents & Colours & Pigments & Rfvalue $(\mathrm{Cm}$. \\
\hline \multirow{3}{*}{ Ethanol } & Light green & Chl A & 0.06 \\
\hline & Yellow green & Chl B & 0.26 \\
\hline & Yellow & Carotenoid & 0.73 \\
\hline \multirow{3}{*}{ Methanol } & Light green & Chl A & 0.5 \\
\hline & Yellow green & Chl. B & 0.60 \\
\hline & Yellow & Carotenoid & 0.67 \\
\hline \multirow{3}{*}{ Acetone } & Light green & Chl.A & 0.25 \\
\hline & Yellow green & Chl B & 0.43 \\
\hline & Yellow & Carotenoid & 0.75 \\
\hline
\end{tabular}
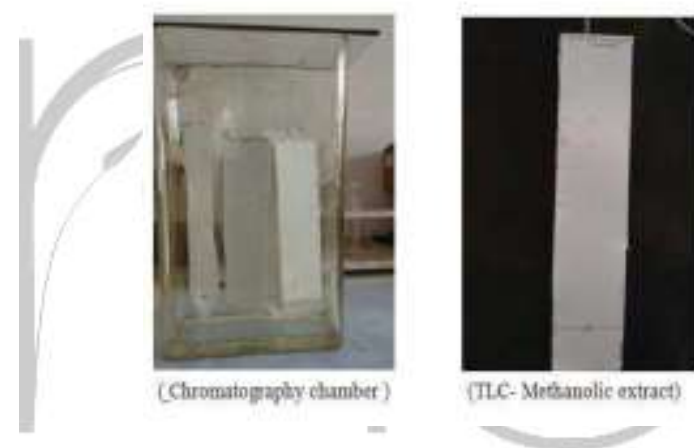

(TIC-Metimolic extract)

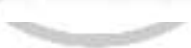

Graph showing the comparison of chlorophyll screening within different solvents.

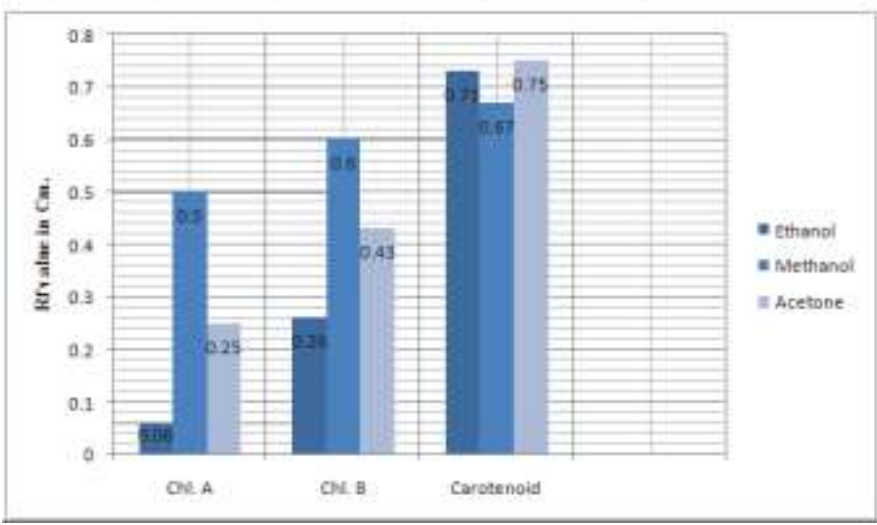

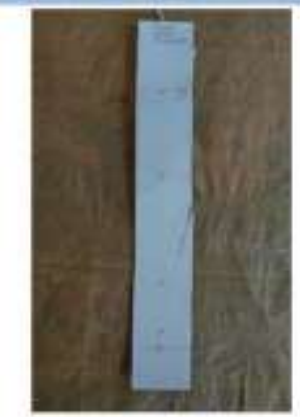

(TLC. Dhanolicestract)

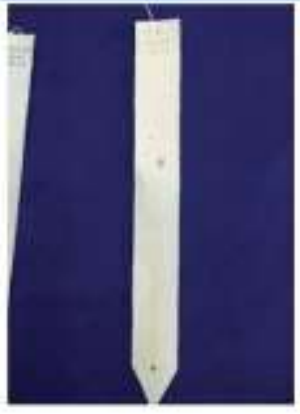

(Papet chromalography-Acetouse)

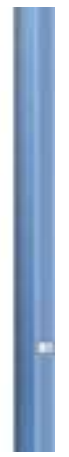


Graphs showing a comparision of chlorophyll amount in between mature \& young leaf of $D$. Stramonium within different slovents.

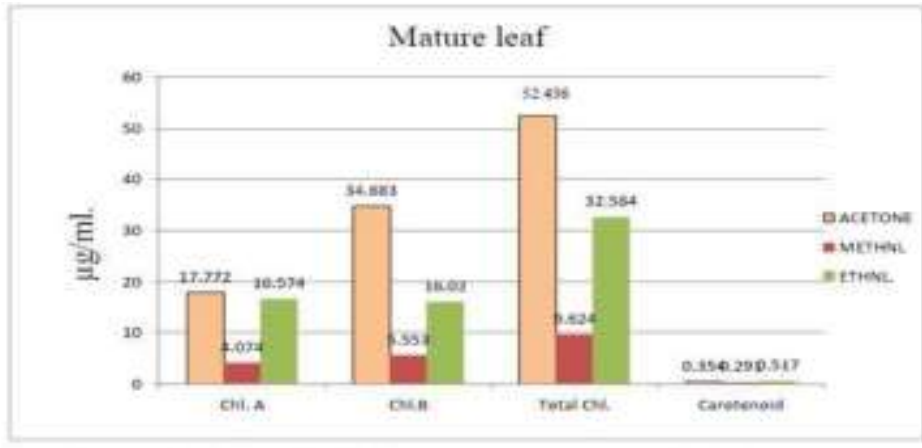

(Graph showing chlorophyll pigments amount comparison in between ACETONE v METHANOLIC v ETHANOLIC extract of mature leaf of Datura stramonium)

\section{Methanolic Extracts}

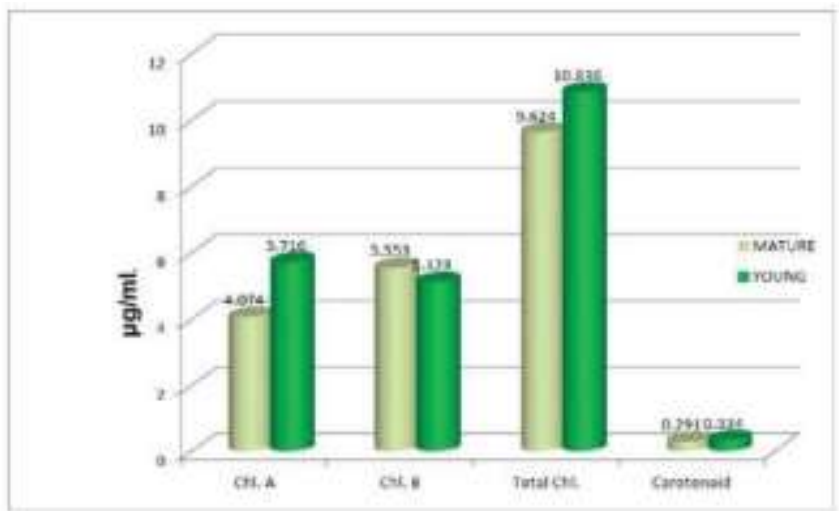

(Graph Showing Chlorophyll amount comparison between mature \& young leaf of Datira stramominm in METHANOLIC EXTRACT)
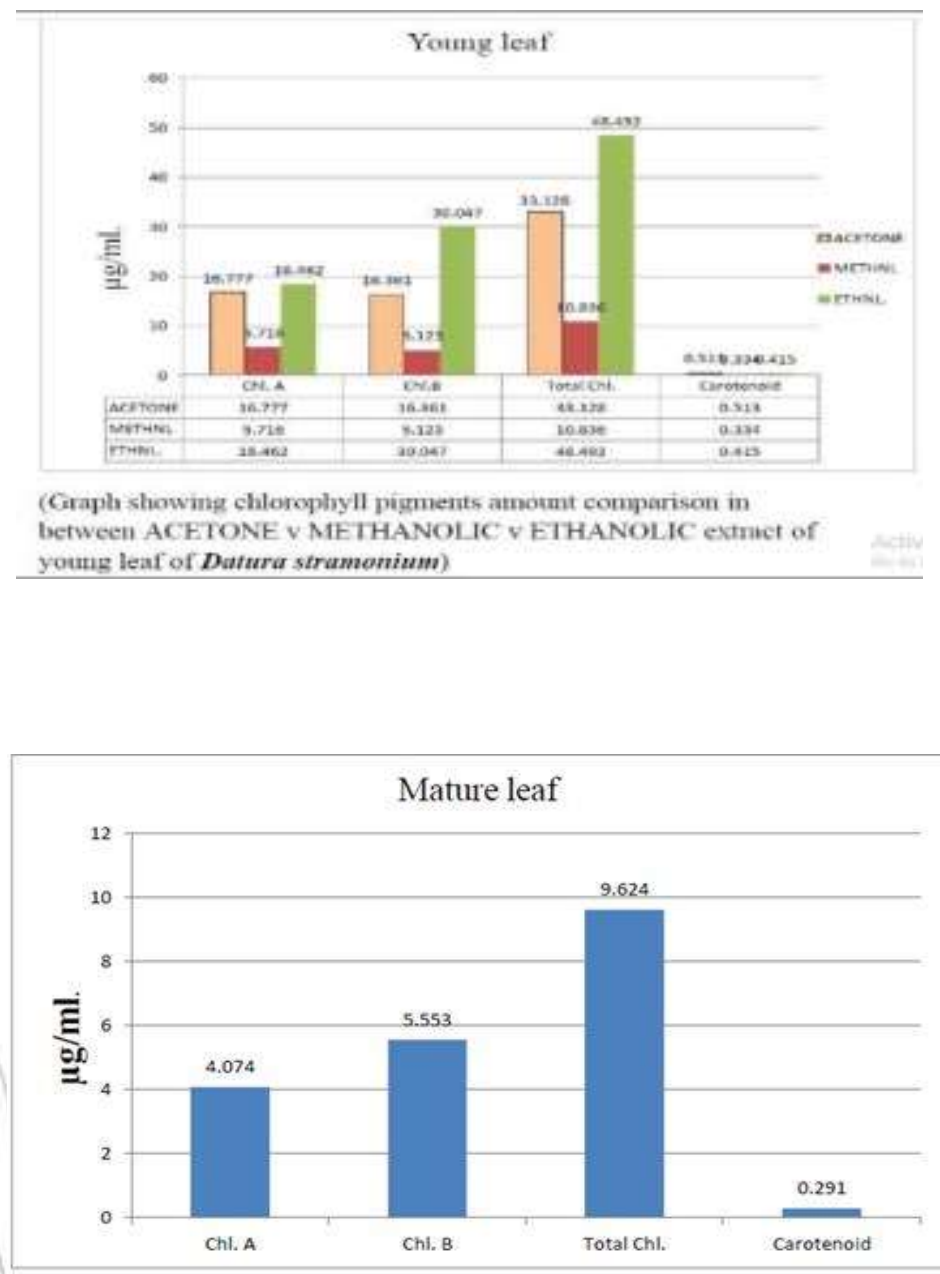

(Graph showing chlorophyll pigments amount comparison present in METHANOLIC EXTRACT of mature leaf of Datura stramonium)

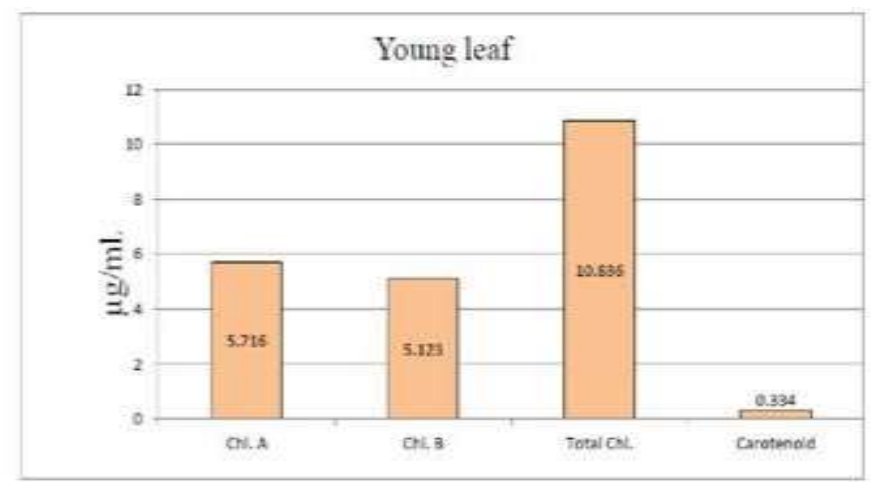

(Graph showing chlorophyll pigments amount comparison present in METHANOLIC EXTRACT of young leaf of Datura stramonium)

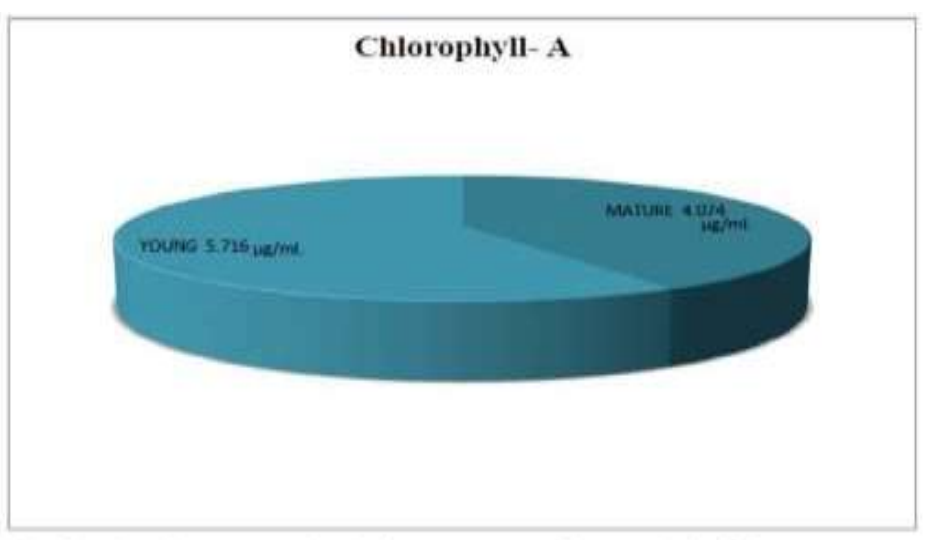

(Pie chart showing a comparison in between mature \& young leaf of Dahura stramonium with chlorophyll- A amount METHANOLIC Extract) 


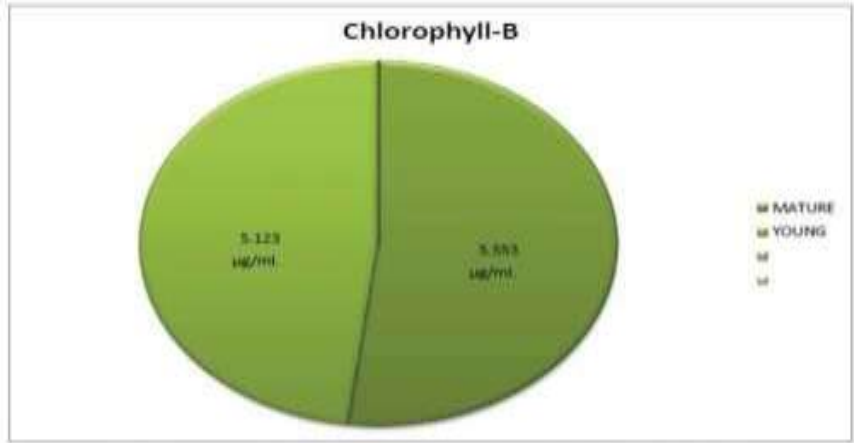

(Pie chart showing a comparison in between mature \& young leaf of Dafura stramenium with chlorophyll- B amount in METHANOLIC Extraet)

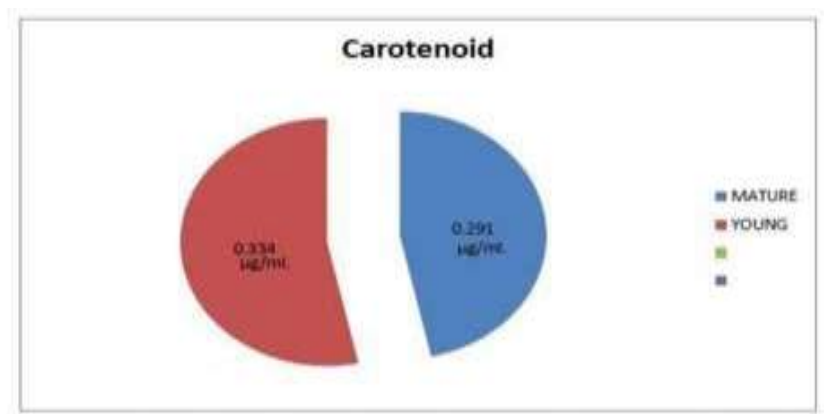

(Pie chart showing a comparison in between mature \& young leaf of Datura stramonium with Carotenoid amount in METHANOLIC Extract)

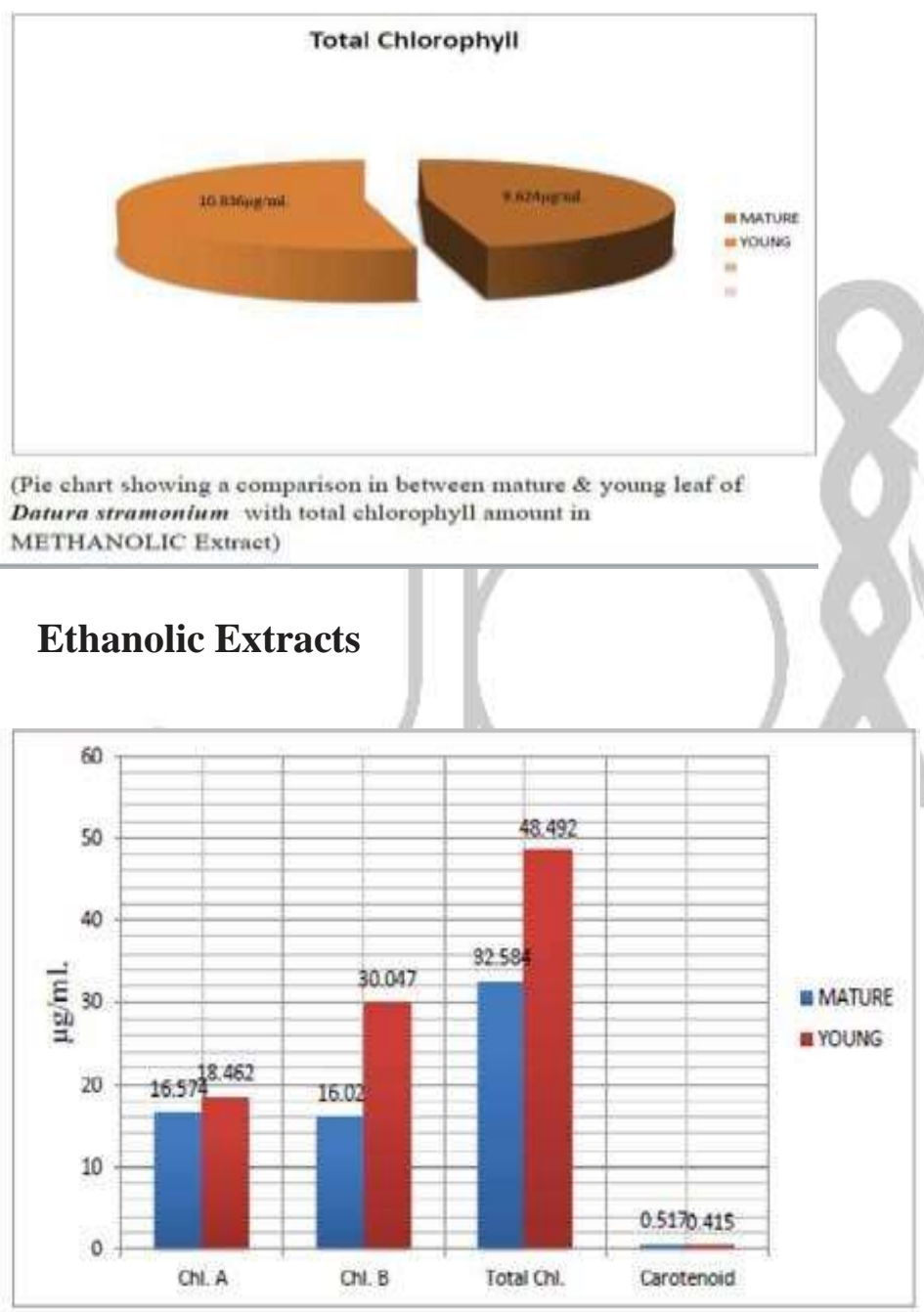

(Graph showing chlorophyll pigments amount comparison in between mature \& young leaf of Datura Stramonium in ETHANOLIC EXTRACT)

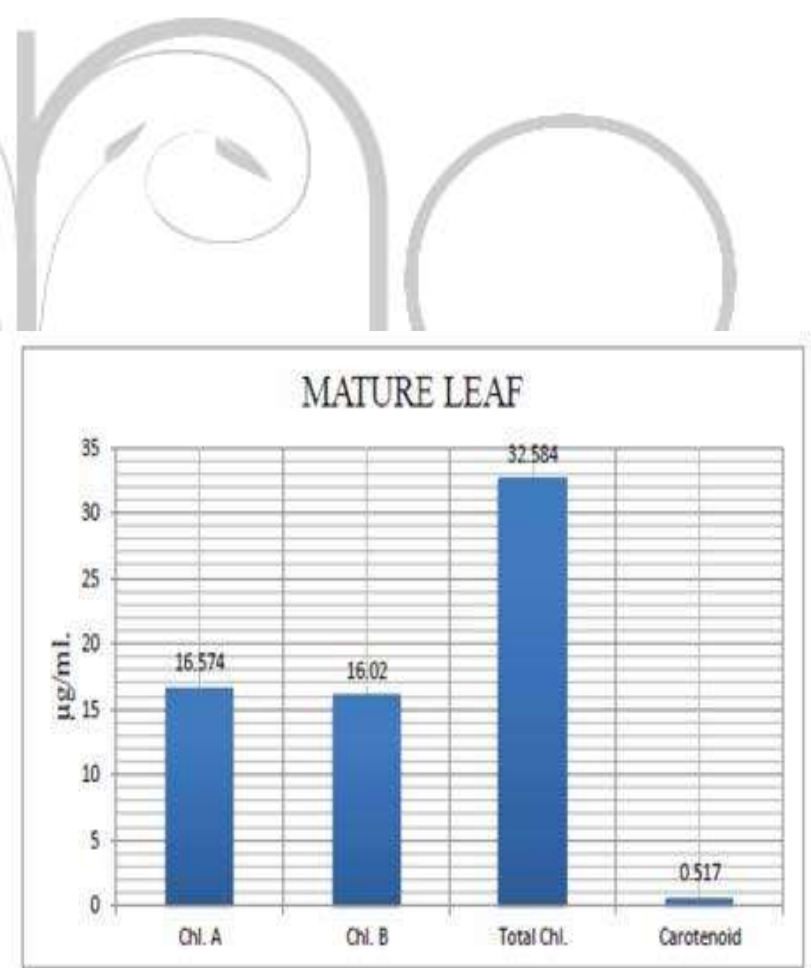

(Graph showing chlorophyll pigments amount comparison in ETHANOLIC EXTRACT of mature leaf of Datura Stramonium) 


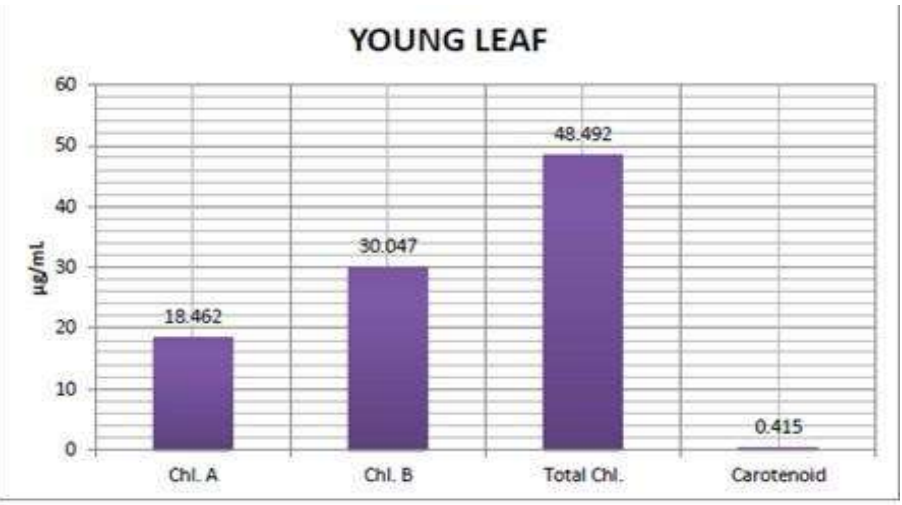

(Graph showing chlorophyll pigments amount comparison in ETHANOLIC EXTRACT of young leaf of Datura Stramonium)

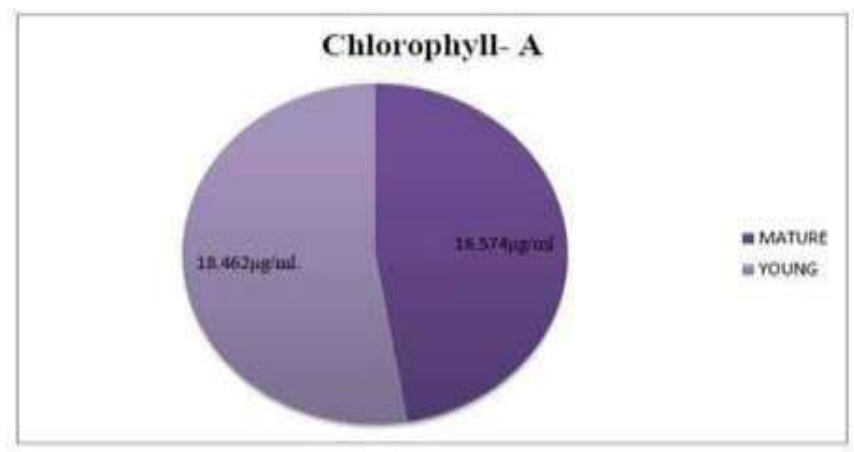

(Pie chart showing chlorophyll - A amount comparison in between mature \& young leaf of Datura Stramonimm in ETHANOLIC EXTRACT)

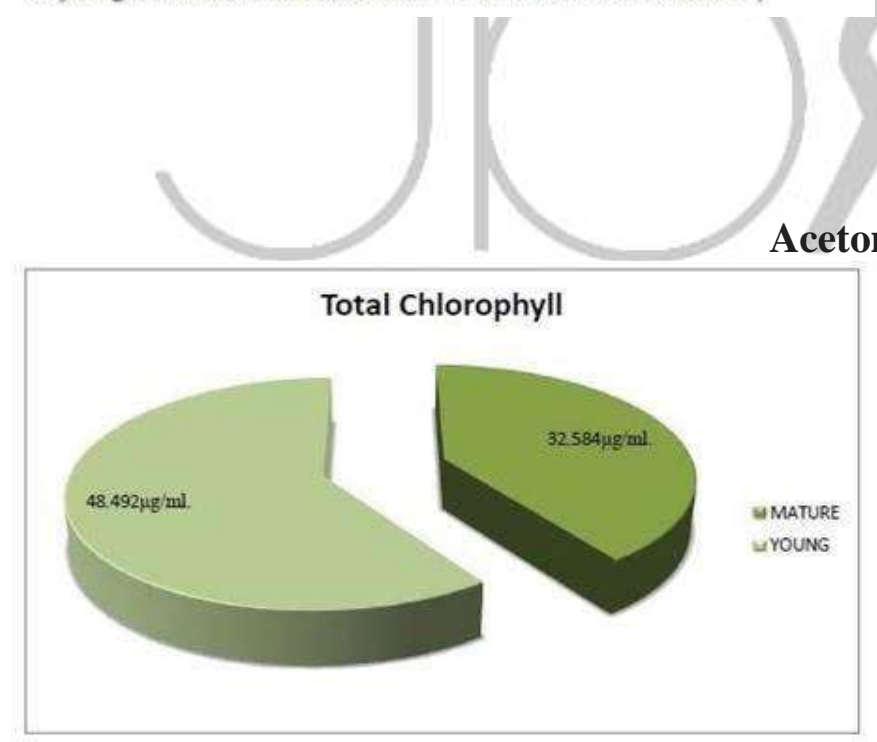

(Pie chart showing total chlorophyll amount comparison in between mature \& young leaf of Datura Stramonium in ETHANOLIC EXTRACT)

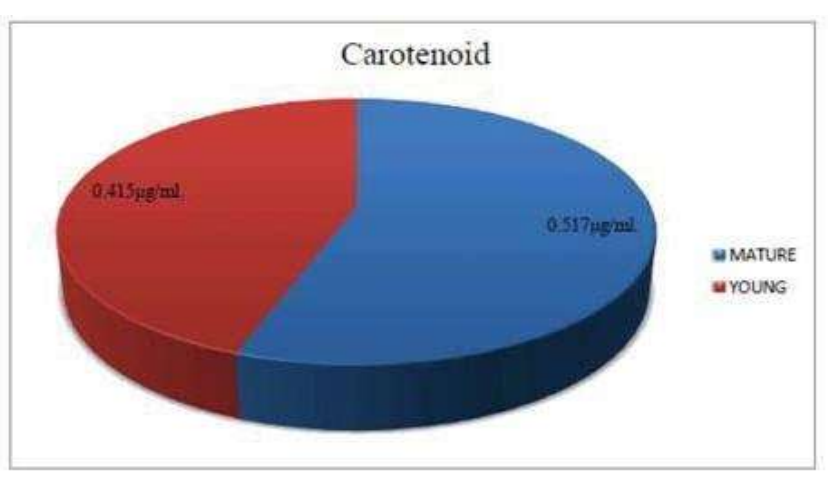

(Pie chart showing Carotenoid amount comparison in between mature \& young leaf of Datura Stramonium in ETHANOLIC EXTRACT)

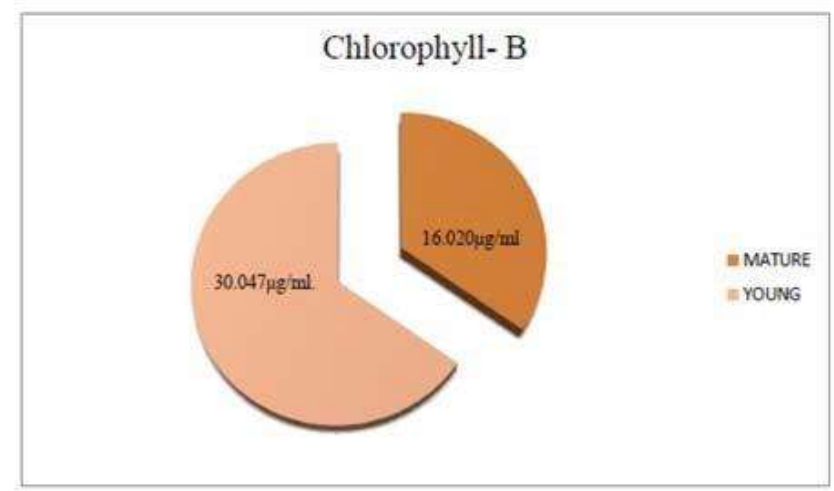

(Pie chart showing chlorophyll -B amount comparison in between mature \& young leaf of Datura Stramonium in ETHANOLIC EXTRACT)
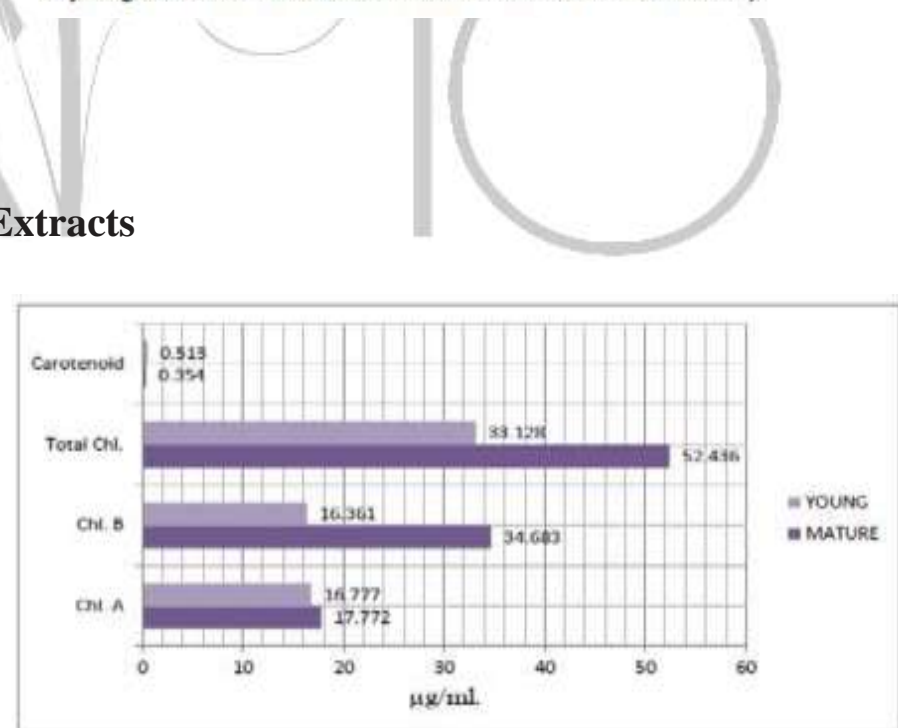

(Graph showing chlorophyll pigments amount comparison in between manure \& young leaf of Datura Stramonium in ACETONE EXTR^CT) 


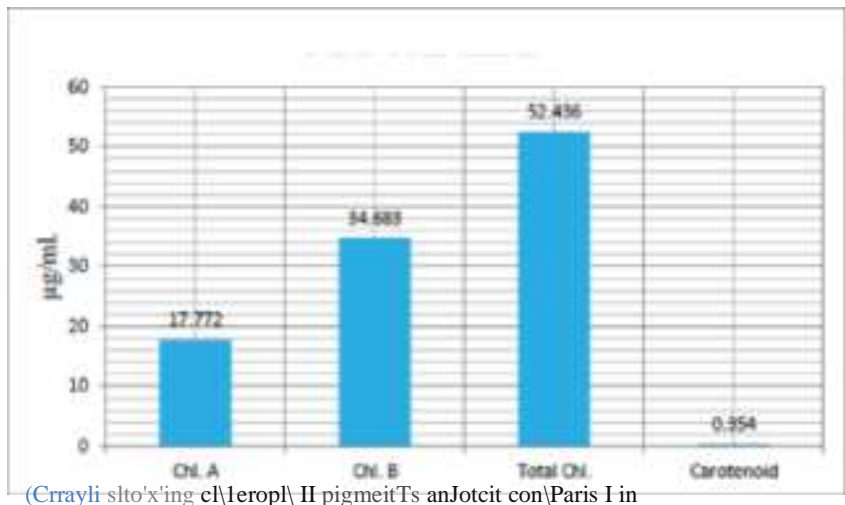

(Crrayli slto'x'ing cllleropl II pigmeitTs anJoteit con\Paris I in murmur )

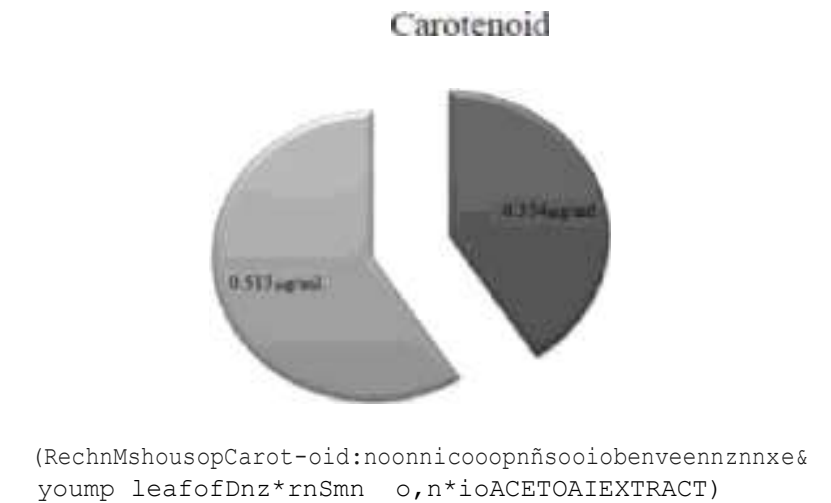

yoump leafofDnz*rnSmn o, n*ioACETOAIEXTRACT)

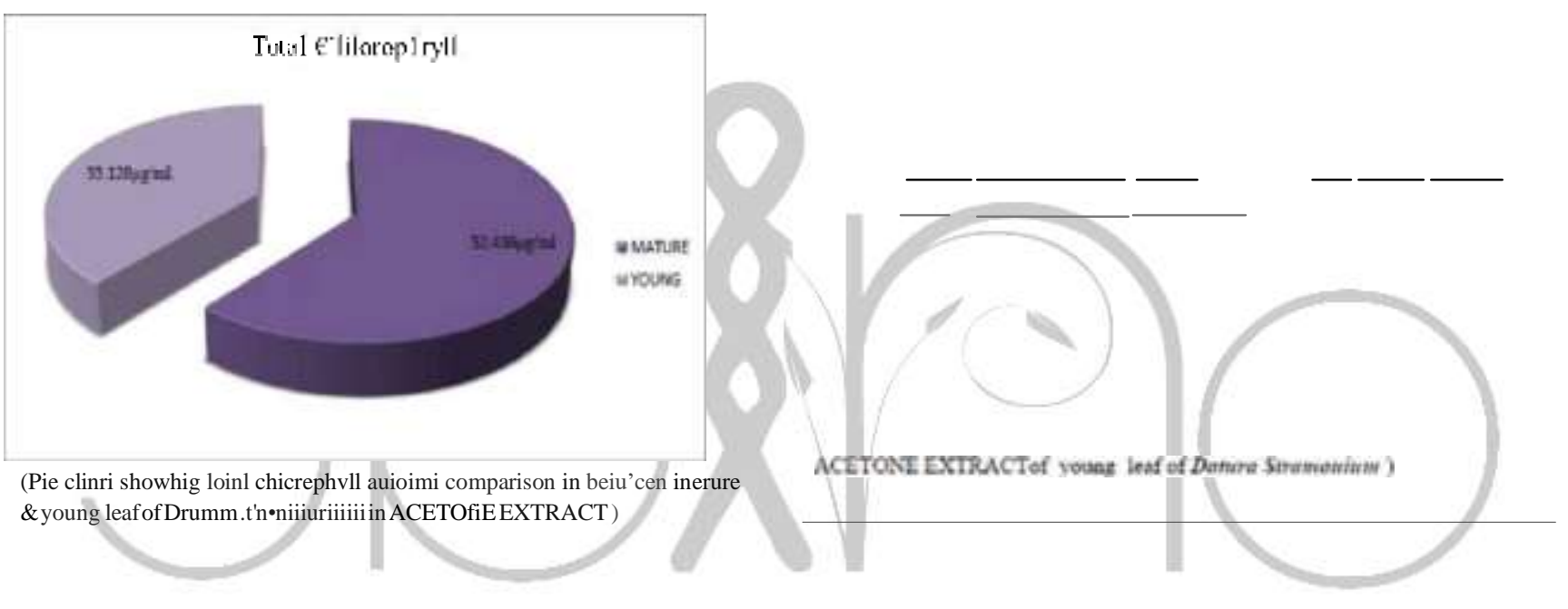

Chlorophyll-A

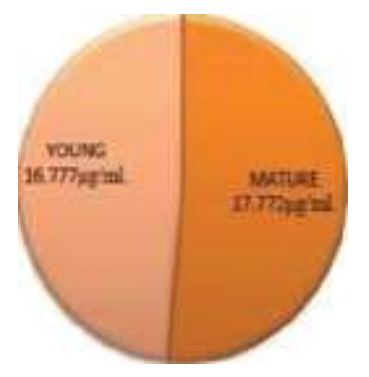

(Pie chair iliou4n2 chlorophs'll -A .unounl coiupsnmu in J/tns'te w me A ix ig leaf of Onrirw A'Jmionii/uni in Afí!ETOñY EXTRACT )
C hl n rnp hyll $\cdot B$

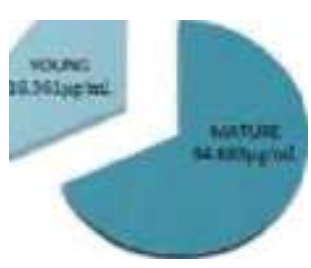

Pie char thowing cllocoptyll $\mathrm{B}$ ameant comparison in between manure \& young leaf of Dancre Serwasuanar in ACETONE EXTRACT) 
Data table for the Screening of anti-microbial activity on $50 \mathrm{mg} / \mathrm{ml}$. of mature $(M)$ \& young $(Y)$ Leaf extract of Datura stramonium of JHwithin different solvents \& different bacterial strain:-

\begin{tabular}{lllc} 
Bacteral strain & Methanol & Ethanol & Controls \\
& M/Y & M/Y & Ampicilin,Streptomycin/ Methanol \\
\hline Staphylococcus & $4 \mathrm{~mm} / 0$ & $5 \mathrm{~mm} / 4 \mathrm{~mm}$ & 0 (Amp.) $/ 0$ \\
& & & \\
E. coli & $6 \mathrm{~mm} / 6 \mathrm{~mm}$ & $6 \mathrm{~mm} / 5 \mathrm{~mm}$ & $6 \mathrm{~mm}$ (Strepto.) $/ 6 \mathrm{~mm}$ \\
\hline
\end{tabular}

$\underline{\text { Kirby-Bauer table of zone diameter interpretative standards for staphylococcus } s p . \&} \underline{E}$. coli as well as for other bacterial strain :-

\begin{tabular}{|c|c|c|c|c|}
\hline \multicolumn{5}{|c|}{ Table 9.1: GUIDELINES CHART } \\
\hline $\begin{array}{c}\text { Antibiotic } \\
\text { (Antimicrobial Agent) }\end{array}$ & DISC CODE & $\begin{array}{l}\text { Resistant } \\
(<\text { or }=\mathrm{mm})\end{array}$ & Intermediate (mm) & $\begin{array}{l}\text { Susceptible } \\
\text { (= or }>\mathrm{mm} \text { ) }\end{array}$ \\
\hline Amoxicillin (other) & AMC & $<13$ & $14-17$ & $>18$ \\
\hline Amoxicillin (Staph) & AMC & 19 & & 20 \\
\hline Ampicillin (other) & AM & 11 & $12-13$ & 14 \\
\hline Ampicillin (Staph) & AM & 28 & & 29 \\
\hline Carbenicillin (other) & $C B$ & 17 & $18-22$ & 23 \\
\hline Carbenicillin (Pseudomonas) & $C B$ & 13 & $14-16$ & 17 \\
\hline Cefoxitin & FOX & 14 & $15-17$ & 18 \\
\hline Cephalothin & $\mathrm{CF}$ & 14 & $15-17$ & 18 \\
\hline Chloramphenicol & c & 12 & $13-17$ & 18 \\
\hline Ciprofloxacin & CIP-5 & 15 & $16-20$ & 21 \\
\hline Clindamycin & $\mathrm{CC}-2$ & 14 & $15-20$ & 21 \\
\hline Enoxacin (Fluoroquinolone, 2nd gen.) & ENX-10 & 14 & $15-17$ & 18 \\
\hline Erthromycin & E & 13 & $14-22$ & 23 \\
\hline Gentamycin & GM & 12 & $13-14$ & 15 \\
\hline Kanamycin & $k-30$ & 13 & $14-17$ & 18 \\
\hline Methicillin (Staph) & M(orDP) & 9 & $10-13$ & 14 \\
\hline Oxacillin (Staph) & ox & 10 & $11-12$ & 13 \\
\hline Penicillin G (Enterococcus) & P & 14 & & 15 \\
\hline Penicillin G (Staph) & 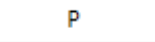 & 28 & & 29 \\
\hline Streptomycin & s-10 & 14 & $15-20$ & 21 \\
\hline Sulfamethoxazole-trimethoprim & SXT & 10 & $11-15$ & 16 \\
\hline Tetracycline & $\mathrm{Te}-30$ & 14 & $15-18$ & 19 \\
\hline Tobramycin & $\mathrm{NN}-10$ & 12 & $13-14$ & 15 \\
\hline Vancomycin & Va- 30 & 9 & $10-11$ & 12 \\
\hline
\end{tabular}

Here, $R=$ Resistance, $\quad I=$ Intermediate, $\quad S=$ Susceptibility 
- According to Kirby-Bauer table of zone diameter interpretative standards the following table is prepared on experimental data:-

\begin{tabular}{|c|c|c|c|c|c|c|c|c|}
\hline \multirow[b]{2}{*}{ ANTIBIOTICS } & \multicolumn{2}{|c|}{ Methanol (M) } & \multicolumn{2}{|c|}{ Methanol (Y) } & \multicolumn{2}{|c|}{ Ethanol (M) } & \multicolumn{2}{|c|}{ Ethanol (Y) } \\
\hline & $\begin{array}{l}\text { Zone of } \\
\text { Dia. }\end{array}$ & $\begin{array}{l}\mathrm{S}, \mathrm{R}, \text { or } \\
\mathrm{I} ?\end{array}$ & $\begin{array}{l}\text { Zone of } \\
\text { Dia. }\end{array}$ & $\begin{array}{l}\mathrm{S}, \mathrm{R}, \mathrm{or} \\
\mathrm{I} \text { ? }\end{array}$ & $\begin{array}{l}\text { Zone of } \\
\text { Dia. }\end{array}$ & $\begin{array}{l}\mathrm{S} \text {, R, or } \\
\text { I? }\end{array}$ & $\begin{array}{l}\text { Zone of } \\
\text { Dia. }\end{array}$ & $\begin{array}{c}\text { S,R,or } \\
\text { I? }\end{array}$ \\
\hline AMPICILIN & $4 \mathrm{~mm}$ & $\mathrm{R}$ & $0 \mathrm{~mm}$ & $\mathrm{R}$ & $5 \mathrm{~mm}$ & $\mathrm{R}$ & $4 \mathrm{~mm}$ & $\mathrm{R}$ \\
\hline $\begin{array}{l}\text { STREPTOMY } \\
\text {-CIN }\end{array}$ & $6 \mathrm{~mm}$ & $\mathrm{R}$ & $6 \mathrm{~mm}$ & $\mathrm{R}$ & $6 \mathrm{~mm}$ & $\mathrm{R}$ & $5 \mathrm{~mm}$ & $\mathrm{R}$ \\
\hline
\end{tabular}

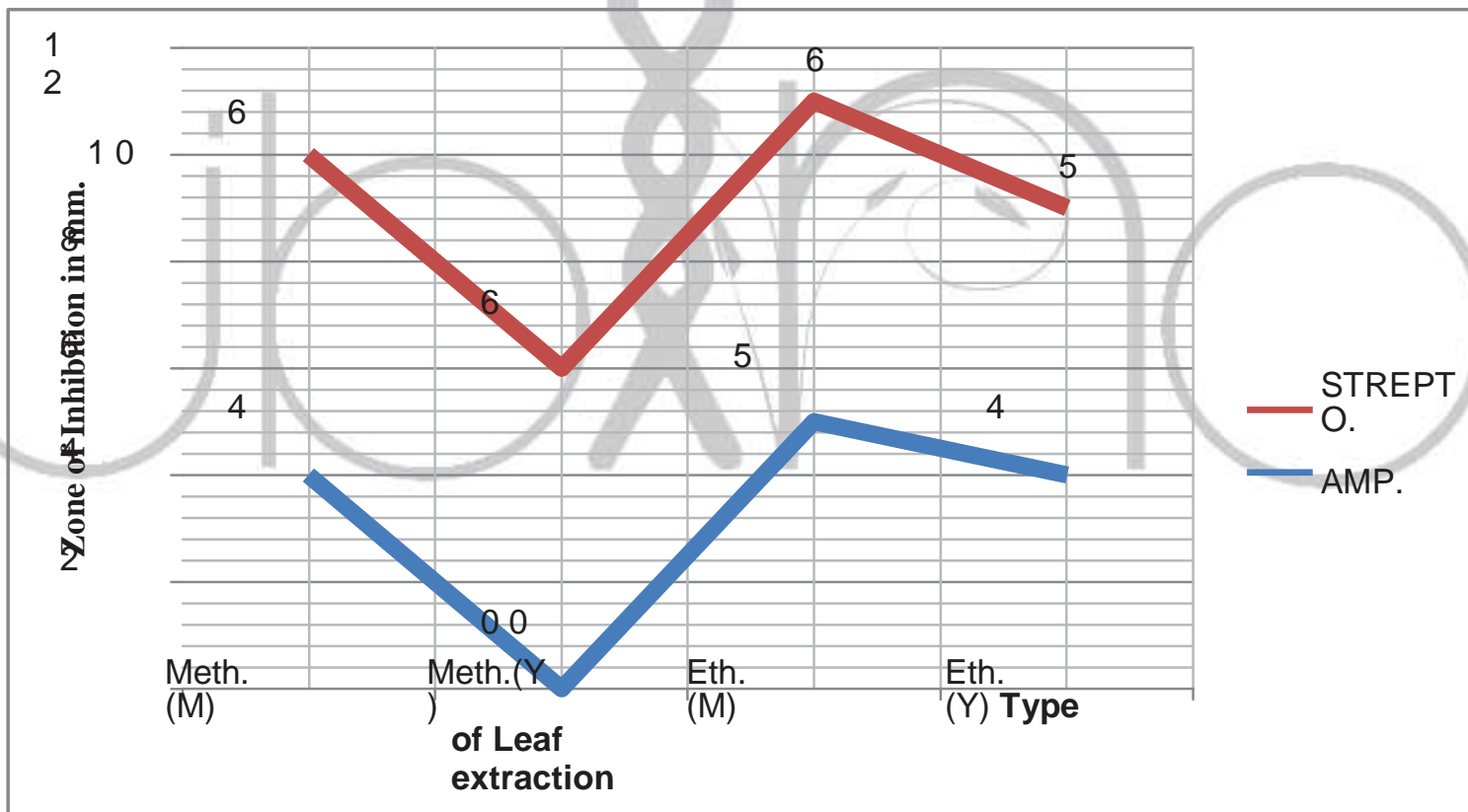

( Graph plotted against two antibiotics, showing comparison of microbial activity of different types of leaf extracts) 
- Table for antibacterial activity of leaf extract of Datura stramonium from different state of INDIA against Ampicilin resistant Staphylococcus aureus

\begin{tabular}{|l|l|l|c|c|l|}
\hline $\begin{array}{l}\text { Sl. } \\
\text { No. }\end{array}$ & $\begin{array}{l}\text { Type of } \\
\text { Extraction }\end{array}$ & \multicolumn{3}{|l|}{ Zone of Inhibition (mm) } & Mean \\
\hline 01 & MH & OD & WB & \\
\hline 02 & Methanol (M) & 4 & 6 & 5 & 5 \\
\hline 03 & Ethanol (M) & 5 & 8 & 6 & 6.33 \\
\hline 04 & Ethanol (Y) & 4 & 9 & 1 & 1.33 \\
\hline
\end{tabular}

- Table for antibacterial activity of leaf extract of Datura stramonium from different state of INDIA against Streptomycin resistant E.coli.

\begin{tabular}{|l|l|l|c|c|l|}
\hline $\begin{array}{l}\text { Sl. } \\
\text { No. }\end{array}$ & $\begin{array}{l}\text { Type of } \\
\text { Extraction }\end{array}$ & \multicolumn{3}{|l|}{ Zone of Inhibition (mm) } & Mean \\
\hline 01 & MH & OD & WB & \\
\hline 02 & Methanol (M) & 6 & 6 & 5 & 5.66 \\
\hline 03 & Ethanol (M) & 6 & 7 & 6 & 6.33 \\
\hline 04 & Ethanol (Y) & 5 & 8 & 5 & 6 \\
\hline
\end{tabular}


The aim of the study was to determine the allelopathic effect of leaf extract of D. Stramonium on leaf chlorophyll content. The range of chl. A, Chl. B, \& Carotenoid were found. Phytochemical screening on medicinal plant play an important role in the detection of the bioactive principle which is a new source of therapeutically and industriallly

valuable

compounds

result showed the reduction in total chlorophyll content. Phyto-chemical study helps to identify active constituents which are responsible for bringing out drug action. It also provides preliminary information on the quality of the drug. Fresh leaves of Datura stramonium collected and are crushed with Acetone, Methanol, \& Ethanol. Few drops of extract taken for TLC \& paper chromatography screening.

The detected alkaloids by TLC plates insured that all the extracts of D. Stramonium contain hyoscine, the atropine appear only in the spot of the seeds under the U.V lamp. $10 \mathrm{ml}$. of each extraction taken in centrifugal tube \& The centrifuge machine ran at approx. $5000 \mathrm{rpm}$ to extract the supernatant to its purest level. The ethanolic,methanol \& acetone extraction shows different behavior at 663 and $645 \mathrm{~nm}$. For the estimation of Carotenoid compound the wavelength set at 500 $\mathrm{nm}$. In Ethanolic \& Methanolic extract the chlorophyll content in young leaf is higher than mature leaf but in acetone the mature leaf has higher chlorophyll content than young leaf. The chlorophyll molecules have great medicinal values like Chlorophyll plays an important role in making plants green and healthy. It also has vitamins, antioxidants, and therapeutic properties that may benefit to body. Research Shows the Health Benefits of Eating a ChlorophyllRich Diet.
For the antibacterial screening we need powedary extract D. stramonium leaf. $100 \mathrm{gm}$. of leaf extract taken. Before that $D$. stramonium plant was collected from different states of India like Jharkhand, Odisha, West-bengal. This research is about to study the antimicrobial capablities of $D$. stramonium from different regions. The anti- microbial

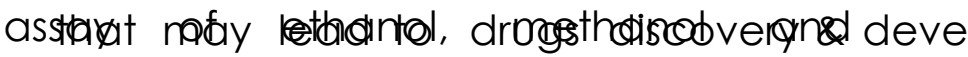
acetone extract of young \& old leaves were prepared by disc diffusion method. 10ul. of standard inoculum of E. Coli \& Staphylococcus ( S. aureus) was spreaded over steriled nutrient agar plates. After that each solvent extract placed with $6 \mathrm{~mm}$ disc size. Plates are culture for $24 \mathrm{hrs}$. at $37^{\circ} \mathrm{C}$. The staphylococcus is gram +ve \&

E. Coli is gram -ve bacteria. Plant based antimicrobial compounds have enormous therapeutical potential as they can serve the purpose without any side effects that are often associated with synthetic antimicrobials ${ }^{11}$ The whole interpretation is done with reference to Kirby- Baver standard table.

\section{Conclusion_}

The whole study which was carried out on a ethno-medicinal \& poisonous plant, i.e Datura stramonium. Its leaves and branches extracts show high anti-microbial activities. In chlorophyll screening experiment it is concluded that, methanolic extract of Datura leaf shows apparently high activity on pigment extraction. Ethanolic extract is lower in this case and Acetone

extract shows avarage activity. After estimating chlorophyll amount it is concluded that in Ethanolic \& Methanolic extract the chlorophyll content in young leaf is higher than mature leaf but in acetone the mature leaf has higher chlorophyll content than young leaf. Qualitative study of primary metabolite 
(plant pigment) was carried out by normal paper chromatography and quantitate study was done by

Arnon method. In the present work, the antibacterial activity of $D$. stramonium leaf with 3 different solvents was investigated. Results of this study indicate that $D$.

aureus \& E. Coli. Highest activity shown with E. Coli in all types of leaf extract used. Both the antibiotics Ampicilin \& Streptomycin show good resistance but somehow fails to show intermediation \& susceptiblity.

\section{REFERENCES}

1. Akharaiyi FC, Antibacterial, Phytochemical and Antioxidant activities of Datura metel. Int. J. PharmTech Res. 2011, 3 (1): 478-83.

2. Ahad HA, Babu UA, Nagesh K, Kiran DS, Madhavi KB. Fabrication of glimepiride Datura stramonium leaves mucilage and poly vinyl pyrrolidone sustained release matrix tablets: in vitro evaluation. Kathmandu university journal of science, engineering and technology 2012;8(1):6372.

3. Buchanan GA, Hoveland CS, Harris MC, 1975. Response of weeds to soil pH. Weed Science, 23(6):473-477.

4. Farombi EO, African indigenous plants with chemotherapeutic potentials and biotechnological approach to the production of bioactive prophylactic agents. African journal of biotechnology. 2003, 2: 662-671.

5. Guarrera PM. Traditional antihelmintic, antiparasitic and repellent uses of plants in Central Italy. Journal of Ethnopharmacology $1999 ; 68(1-3): 183-$ 192.

6. Holm LG, Doll J, Holm E, Pancho JV, Herberger JP, 1997. World Weeds: Natural
Histories and Distribution. New York, USA: John Wiley \& Sons Inc.

7. Okoye TC, Akah PA, Okoli CO, Ezike $A C$, Mbaoji FN, Antimicrobial and antispasmodic activity of leaf extract and fractions of Stachytarpheta cayennensis.

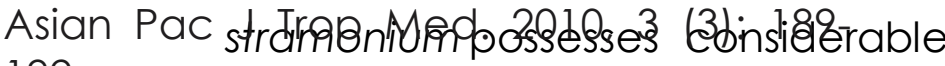
192.

8. T. Efferth and E. Koch, "Complex interactions between Phytochemicals. The Multi- Target Therapeutic concept of Phytotherapy," Current Drug Targets, vol. 12, no. 1, pp. 122-132, 2011

9. Bernstein, P. S.; Li, B; Vachali, P. P.; Gorusupudi, A; Shyam, R; Henriksen, B. S.; Nolan, J. M. (2015). "Lutein, Zeaxanthin, and meso-Zeaxanthin: The Basic and Clinical Science Underlying Carotenoidbased Nutritional Interventions against Ocular Disease". Progress in Retinal and Eye Research. 50: 34- 66. doi:10.1016/j.preteyeres.2015.10.003. PMC 4698241. PMID 26541886.

10.

Shoforowa A. Introduction to medical plants and traditional medicine spectrum book limited. 1993, 224-227.

11.

Yabuzaki, Junko (2017-01-01). "Carotenoids Database: structures, chemical fingerprints and distribution amongorganisms". Database. 2017 (1). doi:10.1093/database/bax004. PMC 5574413. PMID 28365725 